\title{
ВИЗУАЛЬНОЕ БИНАРНОЕ ТЕСТИРОВАНИЕ СЕРОВОДОРОДА, РАСТВОРЕННОГО В ВОЗВРАТНЫХ ПОПУТНО-ПЛАСТОВЫХ ПОДЗЕМНЫХ ВОДАХ НЕФТЕГАЗОКОНДЕНСАТНЫХ МЕСТОРОЖДЕНИЙ
}

Решетняк Е.А. ${ }^{1}$, Немец Н.Н. ${ }^{2}$, Островская В.М. ${ }^{3}$, Чернышёва О.С. ${ }^{4}$, Пантелеймонов А.В.

${ }^{1}$ Харьковский национальный университет им. В.Н. Каразина, Харьков, Украина

${ }^{2}$ Украинский НИИ природных газов Акционерного общества "Укргаздобыча", Харьков, Украина

${ }^{3}$ ФАУ «25 Государственный научно-исследовательский институт химмотологии Министерства обороны Российской Федерации», Москва, Россия

${ }^{4}$ Государственное научное учреждение "Научно-технический комплекс «Институт монокристаллов» НАН Украины, Харьков, Украина reshetnyak@karazin.ua

DOI: 10.26902/ASFE-11_189

В процессе добычи нефти и газа на поверхность поступают большие объемы высокоминерализованной попутно-пластовой воды (ППВ). Утилизация этой воды невозможна или требует высоких материальных затрат. Чтобы не нарушать природного гидродинамического равновесия, воду подготавливают, отстаивают и возвращают в недра глубоких горизонтов нефтегазоконденсатных месторождений. Химический состав возвратной воды должен соответствовать нормируемым показателям, в частности, содержание растворенного $\mathrm{H}_{2} \mathrm{~S}$ не должно превышать $\mathrm{c}_{\text {пред. }}=15 \mathrm{мг} /$ л.

Для визуального скрининг-контроля содержания $\mathrm{H}_{2} \mathrm{~S}$ в образцах возвратной ППВ авторами предложено использовать один образец сравнения. Для исследования были выбраны две индикаторные реакции, протекающие в растворах - образование стабилизированной суспензии $\mathrm{MnS}$ или $\mathrm{CdS}$. Суспензии, приготовленные при $\mathrm{pH} 9$ в присутствии желатина (стабилизатора), были устойчивы в течение суток. Мутность суспензий сопоставляли на черном фоне при боковом рассеянном дневном освещении. Значение концентрации $\mathrm{H}_{2} \mathrm{~S}$ в образце сравнения, которую называли пороговой концентрацией ( $\left.\mathrm{c}_{\text {сравн }}\right)$, установили экспериментально, применяя статистический подход [1, 2]: выявили концентрационный интервал ненадежности $(И Н)$, в котором частота обнаружения различий в мутности образцов сравнения и нормируемого образца (соответствующего с пред.), Р(c), менялась от 0 до 1; эмпирическую зависимость Р(c), полученную из 50 наблюдений мутности 8-11 образцов сравнения в ИН, описали функцией нормального и логнормального распределений; при

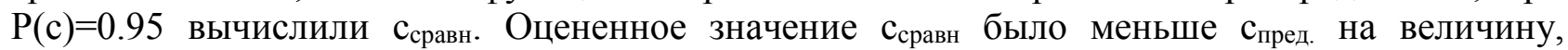
обеспечивающую риск ложноотрицательного результата тестирования не более 5\% - 11.6 мг/л для $\mathrm{MnS}$ и 13.4 мг/л для $\mathrm{CdS}$. В дальнейших тестированиях использовали только суспензию CdS, т.к. она имела лучшие аналитические характеристики.

Проведено визуальное бинарное тестирование $\mathrm{H}_{2} \mathrm{~S}$ в пробах возвратной ППВ из районов газодобычи Харьковской области. Правильность тестирования подтвердили спектрофотометрическим методом определения $\mathrm{H}_{2} \mathrm{~S}$ с $n$-фенилендиамином. Взаимодействие $\mathrm{H}_{2} \mathrm{~S}$ с реагентом проходило в кислой водно-метанольной среде в присутствии $\mathrm{Fe}(\mathrm{III})$. После смешивания растворы нагревали 10 мин на водяной бане, охлаждали, оставляли в темном месте на 15 мин и фотометрировали при 595 нм.

\section{Список литературы}

1. Решетняк Е.А., Немец Н.Н., Пантелеймонов А.В., Шугай Е.А., Холин Ю.В. Создание образца сравнения для бинарного тестирования железа(III) в подземных водах // Вестник ХНУ, Серия Хімия. 2008. Вып. 16(39). С. 146. 2. Решетняк Е.А., Солоха А.Ю., Хаджикова А.А., Пантелеймонов А.В. Образцы сравнения для визуального бинарного тестирования в субстанции хлоргексидина // Методы и объекты хим. анализа. 2017. Т. 12. № 3. С. 123. 